\title{
Evaluation of pheasant semen production during the reproductive season
}

\author{
C Mantovani 1, S Cerolini 2, F Bellagamba 1, MG Mangiagalli 1, \\ LG Cavalchini 1
}

1 Istituto di Zootecnica, Facoltà di Medicina Veterinaria, Via Celoria 10, I-20133 Milano MI; 2 IDVGA-CNR, Via Celoria 10, I-20133 Milano MI, Italy

(Received 2 October 1992; accepted 8 August 1993)

\begin{abstract}
Summary - The aim of this research was to evaluate the quality and quantity of semen production of pheasants during the reproductive season. Fifty-five male pheasants (Phasianus colchicus mongolicus) were used from 37-59 weeks of age. Semen samples were collected manually on a biweekly basis. At 45 weeks of age, pheasants which had never produced $(n=22)$ or only produced occasionally $(n=7)$ were discarded from the study. The volume of the ejaculate from each male was measured upon each semen collection. Sperm concentration and motility were measured for every semen collection from the 41 st week of age. Body weight was recorded at 38 and 39 weeks and then every 2 weeks. The largest percentage $(55 \%)$ of males producing semen was reached at 44 weeks of age. Semen variables showed the following mean values during the reproductive season: volume $=105 \mathrm{mg}$, concentration $=5.86 \times 10^{9} / \mathrm{ml}$, and motility scale $=2.45$ (modest-good). Semen variables were significantly influenced by bird and age but not by day of collection.
\end{abstract}

\section{pheasant / Al / semen / reproductive season}

Résumé - Évaluation du sperme chez le faisan commun pendant la saison de reproduction. L'objectif de cette étude était d'évaluer la quantité et la qualité de la semence produite chez le faisan au cours de la période de reproduction. Au total, 55 faisans mâles âgés de 37 à 59 semaines ont été utilisés. La récolte de sperme était effectuée manuellement, toutes les 2 semaines. Les animaux âgés de 45 semaines n'ayant jamais eu de production spermatique $(n=22)$ ou une production occasionnelle $(\mathrm{n}=7)$ ont été éliminés. Les paramètres suivants ont été déterminés sur l'éjaculat individuel : volume, concentration et motilité. Les animaux ont été pesés individuellement à 38 et 39 semaines, puis toutes les 2 semaines. Les mâles âgés de 44 semaines ont été les meilleurs producteurs (55\%). Les caractéristiques de la semence ont été définies par les valeurs moyennes suivantes : volume $=105 \mathrm{mg}$, concentration $=5,86 \times 10^{9} / \mathrm{ml}$, motilité $=2,45$. Les paramètres déterminés sur la semence étaient significativement différents selon les individus et l'âge. Par contre, le jour de collecte n'a pas influencé les résultats.

faisan / insémination artificielle / semence / période de reproduction 


\section{INTRODUCTION}

Reproductive activity of wild pheasants usually starts during the second half of March when males turn into a phase of territorial activity. This period can be identified by territorial singing and can last for 5 months, but sometimes can even be shorter depending of the climatic conditions of the area. Egg deposition begins in March and hatching is distributed along a very variable period of time. Mating behaviour is promiscuous; female pheasants can mate with different males in the same season. This happens because females move across different territories searching for food, water, and nesting sites. Competition between males to rule over a good territory is very high. Sometimes, a dominant male accepts different males in his territory. Those males are called "satellites" because they move across different territories and mate with resident females (Johnsgard, 1986; Meriggi, 1992). In farms, breeders are grouped together in families or colonies and kept in small pens on the ground or in battery cages (Faure et al, 1993). Usually, reproduction is performed by natural mating, and artificial insemination (AI) has been successfully used (Petitjean et al, 1986; Cerolini et al, 1990).

Knowledge of avian semen is obtained basically from artificial insemination (AI) techniques. Al is normally used in turkey and guinea-fowl breeding because firstly, males of the selected strains are almost incapable of mounting because of their excessive weight $(20-25 \mathrm{~kg})$ and second$\mathrm{ly}$, to avoid floor management problems. $\mathrm{Al}$ is necessary in order to reach specific objectives, for example, the application of selection programmes or determination of fertility problems resulting from natural copulation difficulties.

Some broiler production centers have recently introduced $\mathrm{Al}$ into normal breed- ing routines. At present, this technique provides fertility and hatching results superior to those obtained with natural breeding (Van Wambeke, 1990).

For correct $\mathrm{Al}$, the birds' semen production capacity must be known; the qualitative characteristics of the semen should be assessed. The samples are obtained by periodic manual collection throughout the entire reproductive period. This information has already been obtained for some of the avian species which are normally subjected to Al, but not for others which normally breed by natural mounting.

A superficial analysis of semen can be done visually. Good quality semen must be pearly white, dense and lacking in fecal material (Lake and Stewart, 1978). This analysis is normally done on-site, immediately after collection. A more precise qualitative analysis follows covering volume, concentration, motility, and live/dead ratio, the various variables which have been traditionally used to define semen quality (Sexton, 1983; de Reviers, 1985; Jequier and Crich, 1986; Sauveur, 1988; Mariani et al, 1989).

This research aims to assess the quality and quantity of pheasant semen production during the reproduction season on birds from a typical intensive breeding farm.

\section{MATERIALS AND METHODS}

Fifty-five male pheasants (Phasianus colchicus mongolicus) were used. At 37 weeks of age, they were caged separately in 4-tier batteries, in a completely controlled environment $(T=18-$ $20^{\circ} \mathrm{C}$, forced ventilation and artificial light). At the moment of caging, the photoperiod was $11 \mathrm{~h}$ light, $13 \mathrm{~h}$ darkness. The light period was increased by $1 \mathrm{~h}$ each week to reach $14 \mathrm{~h}$ light, $10 \mathrm{~h}$ darkness by 40 weeks of age; this photoperiod was maintained until 59 weeks of age. The pheasants were fed ad libitum with integrat- 
ed commercial feed for breeders (22\% CP and $2833 \mathrm{kcal} \mathrm{ME} / \mathrm{kg}$ ). The week of housing was considered 'rooming-in' and no readings were taken. The individual birds were weighed at 38 and 39 weeks of age and then at a regular 2week intervals.

Semen samples were collected twice a week according to Lake and Stewart's technique (1978). Semen was sampled from all the birds from 38 to 45 weeks of age. Non-producing males ( $n=22$ ) or occasional producers $(n=7)$ were eliminated from the study. So from 46 to 59 weeks of age, the experimental group was reduced to 27 birds which constantly produced semen.

The volume of the ejaculate from each male was measured at every semen collection. Sperm concentration and motility were measured on the single ejaculate every semen collection from the 41st week of age. Because of the small sample quantity, volume was measured indirectly by weight $(\mathrm{mg})$. Semen concentration was measured by spectrophotometry $(\lambda=535$ $\mathrm{nm}$ ) after diluting the fresh semen 1:200 with saline solution $(0.9 \% \mathrm{NaCl})$. The optical density (OD) values were then converted into $10^{9}$ spermatozoa $/ \mathrm{ml}$ using to a reference table specific for bird species (IMV). Semen motility was measured subjectively following videorecording. The fresh semen sample was diluted 1:200 with saline solution $(0.9 \% \mathrm{NaCl})$ and was then examined using a Nikon Optiphot phase microscope with a $20 x$ lens and $10 x$ eyepiece. Percentage motility was scaled as follows: 1) scarce = less than $30 \%$; 2) modest $=31 \%-50 \%$; 3) good $=$ $51 \%-70 \%$; 4) very good $=71 \%-90 \%$; 5) excellent $=$ more than $91 \%$.

The experiment continued throughout the male reproductive season from 37 to 59 weeks of age, which corresponded to the period February 11 to July 11 in 1991. The data were processed by variance analysis using the GLM procedure of SAS ${ }^{\circledR}$ (SAS Institute, 1985). The bird and its age were used as sources of variation for the body weight variable. The bird and the sampling day were also used as sources of variation and the bird's age as a co-variate for the variables semen volume and concentration. Motility was analyzed by non-parametric variance analysis using the N1PARWAY procedure of SAS ${ }^{\circledR}$ (SAS institute, 1985) using the same sources of variation considered for the previous semen variables. Correlations were calculated among the semen variables (SAS Institute, 1985).

\section{RESULTS}

The variables measured over the whole experimental period are reported in table 1. Analysis of variance showed that body weight and semen variables were significantly influenced by the bird and its age; however, the day of sampling was of no statistical significance (table II).

The male pheasants decreased in weight during the reproductive period until 53 weeks of age from $1600 \mathrm{~g}$ to $1470 \mathrm{~g}$; the body weight did not change from 53 to 59 weeks (fig 1). Semen production was evident in some birds from the first manual collection at 38 weeks of age (fig 2). The number of males in semen production progressively increased over the following weeks. The largest percentage of males producing semen (55\%) was recorded at 44 weeks of age. Non-producing males or occasional producers were discarded from the study at 45 weeks of age. Therefore, from 46 to 59 weeks of age, the experimental group was reduced to the 27 best producers. The percentage of males producing semen at each single collection was never $100 \%$, even with this select group of males. Nevertheless, the percentage of males in semen production was high and always above $80 \%$, until the birds were 56 weeks of age when it decreased

Table I. Experimental parameters measured on male pheasant breeders during the reproductive season.

\section{n mean SE}

\begin{tabular}{llll}
\hline Body weight $(\mathrm{g})$ & 455 & 1547 & 5.83 \\
$\begin{array}{l}\text { Semen variables : } \\
\text { Volume }(\mathrm{mg})\end{array}$ & 835 & 105 & 0.003 \\
Concentration $\left(\times 10^{9} / \mathrm{ml}\right)$ & 629 & 5.86 & 0.09 \\
Motility & 652 & 2.45 & 0.03
\end{tabular}

$n$ : number of observations; SE: standard error 
Table II. Results of analysis of variance. Results for weight, semen volume and concentration are from a GLM procedure, results for semen motility are from a N1PARWAY procedure.

\begin{tabular}{|c|c|c|c|c|c|c|}
\hline & \multicolumn{2}{|c|}{ male } & \multicolumn{2}{|c|}{ age } & \multicolumn{2}{|c|}{ day } \\
\hline & $F$ & $P$ & $F$ & $P$ & $F$ & $P$ \\
\hline Body weight & 32.23 & 0.0001 & 22.92 & 0.0001 & - & - \\
\hline Volume & 9.64 & 0.0001 & 40.14 & 0.0001 & 0.02 & 0.88 \\
\hline Concentration & 6.64 & 0.0001 & 56.47 & 0.0001 & 0.94 & 0.33 \\
\hline Motility & 106.7 & 0.0001 & 60.8 & 0.0001 & 0.38 & 0.54 \\
\hline
\end{tabular}

P: probability; F: F-value - the ratio produced by dividing MS/(model) by MS/(error).

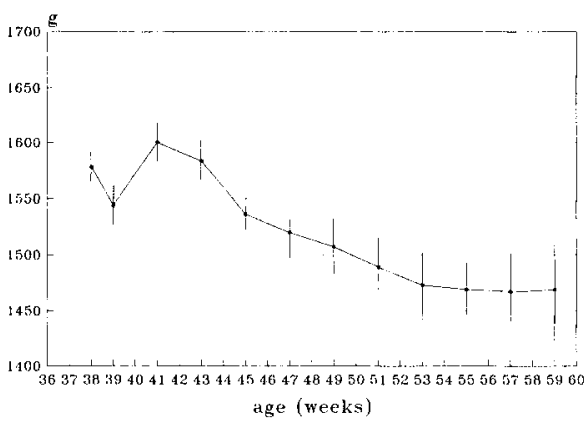

Fig 1. Mean body weight (g) of male pheasants during the reproductive season.

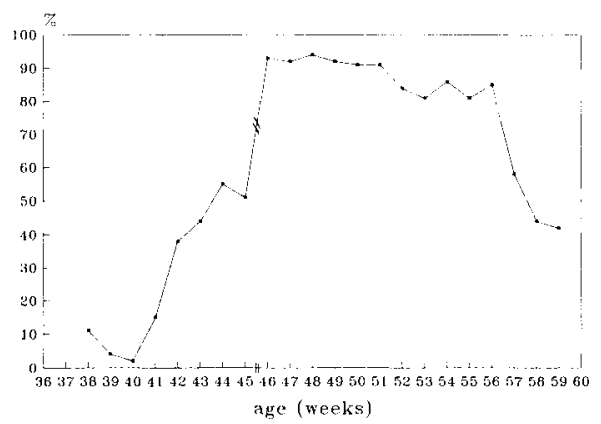

Fig 2. Percentage of males phesants producing semen during the reproductive season. From 38 to 45 weeks of age $n=55$; from 46 to 59 weeks of age $n=27$. progressively to reach a minimum value of $42 \%$ in correspondence with the end of the reproductive period, at 59 weeks of age.

Individual semen production was much lower compared with other bird species. The trend of the mean ejaculate weight during the reproductive period is reported in figure 3. From analysis of variance, there was a significant but very small positive regression between volume and age $(b=0.003 ; P<0.001)$. In fact, semen production was quite poor until 44 weeks of age. In the weeks that followed, it increased and stabilized between 106 and $146 \mathrm{mg}$.

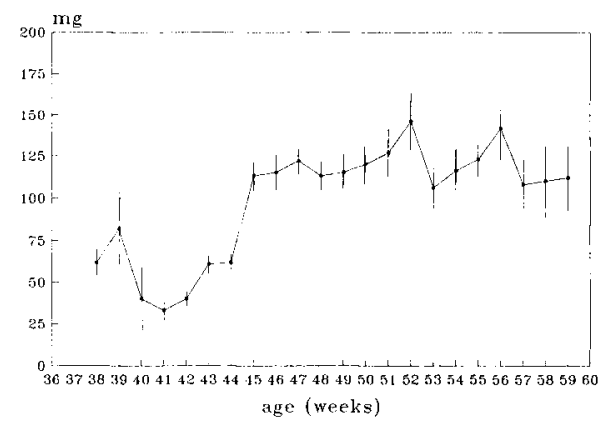

Fig 3. Mean volume weight $(\mathrm{mg})$ of the ejaculate in pheasants during the reproductive season. 
A negative regression was found between semen concentration and age $(b=-0.126 ; P<0.001)$. It increased gradually to values between 6 and $7 \times 10^{9}$ spermatozoa/ml from 45 to 53 weeks of age (fig 4). The mean values during the final weeks were between 4 and $5 \times 10^{9}$ spermatozoa/ml.

Semen motility was relatively constant throughout the reproductive period, with the highest values registered during the last experimental weeks (fig 5). Significant small positive correlations between volume and concentration $(r=0.158 ; P=0.0001)$ and between concentration and motility ( $r$ $=0.099 ; P=0.014$ ) were calculated. The correlation between motility and volume was not significant $(r=0.008 ; P=0.832)$.

\section{DISCUSSION}

The quantitative and qualitative characteristics of semen production in important domestic bird species (chicken, turkey, guinea fowl, duck and goose) used in intensive breeding have been reported in the literature (Lake and Stewart, 1978; Sauveur, 1988). Pheasants are now bred in captivity

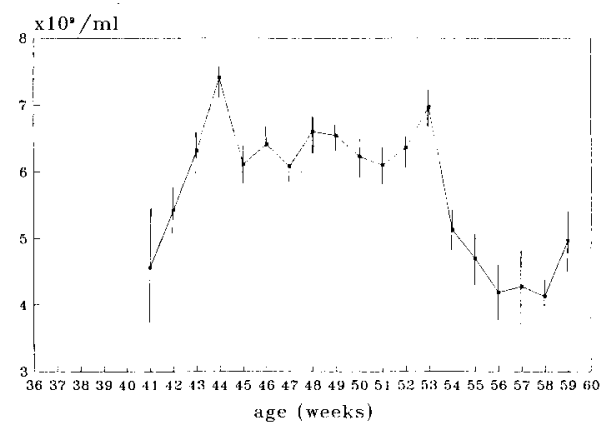

Fig 4. Mean semen concentration $\left(x 10^{9} / \mathrm{ml}\right)$ in pheasants during the reproductive season. according to normal intensive breeding techniques. Nevertheless, a lot is still unknown about its reproductive capacity and the possibilities of improving breeding under these conditions. The characteristics of pheasant semen are different to those of other birds, for example, chicken or turkey.

The amount of semen in each ejaculate was much lower than for other avian species (Lake and Stewart, 1978; Sauveur, 1988). In our study, the mean weight was $105 \mathrm{mg}$ (corresponding to a volume of approximately $105 \mu \mathrm{l}, 1 \mathrm{mg}=1 \mu \mathrm{l}$ ) consistent with other experimental results (Petitjean et al, 1986).

In reference to the adaptation of the pheasant to manual semen collection, it should be emphasized that under the experimental conditions described, a high percentage of males did not produce any semen $(43 \%)$. The same result was found in a preliminary $\mathrm{Al}$ study in pheasants (Cerolini et al, 1990).

Nevertheless, it should be considered that the males used in this experiment originated from a traditional breeding farm with natural copulation and that this was the first time they had been subjected to manual collection of sperm. The percent-

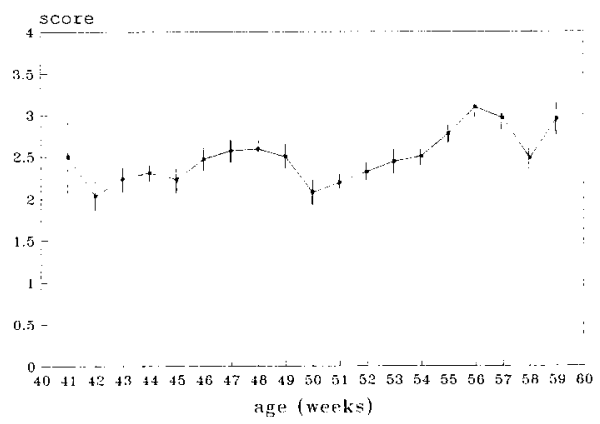

Fig 5. Mean semen motility score in pheasants during the reproductive season. 
age of males producing semen could probably be improved if this technique were used for successive generations, and only the males that give good results with manual collection are used for reproduction.

Selection for semen production has had good results. The number of spermatozoa per ejaculate has good heritability, 0.45 0.50 , and its level was improved significantly by 6 years of selection (Petitjean et al, 1990). Moreover, fertility improves from $85-92 \%$ when breeders are kept in colonies rather than in families (Bagliacca et al, 1990). Individual fertility problems occurs, but they are overcome by the presence of more males.

Body weight decreased $8 \%$ during the reproductive season. The mean body weight measured from 38 to 43 weeks of age was $1576 \pm 19 \mathrm{~g}$, similar to the mean body weight measured in adult wild male pheasants during the winter season (January and February) (Papeschi et al, 1991; Meriggi, 1992). A consistent decrease in body weight $(12 \%)$ was also recorded in female pheasants during egg production (Monetti et al, 1982).

If we consider the quantitative and qualitative characteristics of the semen and presuming that the Al technique will be included in the normal breeding routine, the female/male ratio cannot be increased much beyond natural copulation levels because of the small volume of semen obtained from each collection. Nevertheless, $\mathrm{Al}$ ensured that all the breeders, males and females, contributed to and improved fertility levels within the breeding farms. Breeding farms which have used $\mathrm{Al}$ for several consecutive generations have reported $86 \%$ fertility and $78 \%$ hatching ( $\mathrm{Pe}$ titjean et al, 1986). In traditional breeding farms with natural mounting, fertility was $84 \%$ and hatching was $63.5 \%$ (Trapletti, $1991)$ or varied between $50-58 \%$ and $65-$ $75 \%$ (Mussa and DeBernardi, 1987).

\section{REFERENCES}

Bagliacca M, Ballante M, Paci G, Marzoni M (1990) Tecnologia di allevamento del fagiano: riproduzione in colonia o famiglia. Atti XII Congresso Allevamenti di Selvaggina, Cagliari, 87-95

Cerolini S, Mantovani C, Mangiagalli MG, Rizzi R (1990) Prova preliminare sulla fecondazione artificiale nel fagiano (Phasianus colchicus). Atti XII Convegno Nazionale Allevamenti di Selvaggina, Cagliari, 241-246

de Reviers M (1985) Conduite de l'élevage des coqs reproducteurs de type chair en vue de l'insémination artificielle. CR Conférence Avicole WPSA-SIMAVIP, Paris, 12-13

Faure JM, Melin JM, Mantovani C (1993) Welfare of guinea fowl and game birds. Proc 4th Eur Symp Poultry Welfare, September 18-21, Edinburgh, Scotland, 148-157

Jequier A, Crich J (1986) Semen Analysis, A Practical Guide. Blackwell Sci Publ, Alden Press, UK

Johnsgard PA (1986) The Pheasants of the World. Oxford Univ Press. Oxford, UK

Lake PE, Stewart JM (1978) Male reproductive physiology and the collection of semen. In: Artificial Insemination in Poultry. Bulletin 213, Ministry of Agriculture, Fisheries and Food, 5-14

Mariani P, Cerolini S, Pizzi F (1989) Fecondazione artificiale nei volatili: nuovi parametri $e$ metodiche di valutazione del materiale seminale. Riv Avicoltura 2, 37-41

Meriggi A (1992) Fagiano Comune Phasianus colchicus. In: Aves: Gavidae-Phasianidae, vol XXIX, (P Brichetti, P De Franceschi) Calderini, Bologna, 824-840

Monetti PG, Monge F, Marcomini F (1982) Influenza del livello energetico della razione sulle performances riproduttive del fagiano. Zootec Nutri Anim 8, 115-133

Mussa PP, de Bernardi M (1987) Allevamento e reintroduzione di piccola selvaggina stanziale: situazione attuale eprospettive di miglioramento. Att IX Convegno Gruppo di Studio per gli Allevamenti di Selvaggina, Bastia Umbra, $85-99$

Papeschi A, Narciso F, Briganti F, DessiFulgheri $F$ (1991) Speroni, caruncole e testo- 
sterone plasmatico nel fagiano maschio. Atti del II Convegno Nazional dei Biologi della Selvaggina, Bologna, vol XIX, 661-663

Petitjean M, Guillot P, Malineau G (1986) Maitrise de la reproduction du faisan. 7th Eur Poultry Conf Paris, vol 1, 148-152

Petitjean M, Bencheikh N, Malineau G (1990) Étude de la variabilité de critères de la croissance et de la fertilité chez le faisan commun. In: Control of Fertility in Domestic Birds. (JP Brillard, ed), INRA, Paris, 157-165

SAS Institute Inc (1985) SAS User's guide: statistics, version 5 edition. SAS Institute Inc Cary, NC, USA
Sauveur B (1988) Reproduction des volailles et production d'oeufs. INRA, Paris, 141-181

Sexton TJ (1983) Maximizing the utilization of the male breeder: a review. Poultr Sci 62, $1700-1710$

Trapletti D (1991) Variabilità genetica di alcuni parametri morfologici nel fagiano. Tesi di laurea. Istituto di Zootecnica Veterinaria, Università di Milano

van Wambeke $F(1990)$ Semen preservation above $0^{\circ} \mathrm{C}$ in fowls: interest and current limits for industrial purposes. In: Control of Fertility in Domestic Birds (JP Brillard, ed), INRA, Paris, 177-184 